\title{
DEVELOPMENT OF DESIGN PRINCIPLES DROIT DE PREFERENCE AGAINST OWNERS BUSINESS PREMISES IN TANAH ABANG JAKARTA
}

\author{
PENGEMBANGAN MODEL ASAS DROIT DE PREFERENCE TERHADAP \\ KEPEMILIKAN TEMPAT USAHA PADA \\ PASAR TANAH ABANG JAKARTA
}

\author{
Ilman Khairi, Martin Roestamy*
}

ilman.khairi@unida.ac.id

(Diterima pada: 05-06-2017 dan dipublikasikan pada: 01-12-2017)

\begin{abstract}
Use Rights Certificate Business Place (SHPTU) is proof of ownership of the right to use business premises (shop) in a market that is owned by market traders. SHPTU have a fairly high economic value. Therefore expected SHPTU can be used as loan collateral. SHPTU have a common element of the lease, as in article 1548 of the Civil Code. Because SHPTU not the right material, then SHPTU can not be guaranteed by using a material guarantee institutions. This thesis research methods with the added element of normative juridical empirical, with the analysis of qualitative data. From the analysis it can be concluded that SHPTU not the right material, but given SHPTU has economic value and can be transferred, it is expected that the government can immediately respond to the needs of society (the Merchants Market) to the existence of a guarantee institution which can accommodate SHPTU shop as loan collateral. Resulting from the rigidity of the legal material to deliver the right material on business premises or SHPTU recommended for use kaedah contained in Article 48-49 of the legislation Flats by issuing Certificates of Building Owners and Building (SKBG), where the issuance of the certificate is the same between Local government in this case the Department of Public Works and the Department of Housing, while still managing $P D$ Pasar Jaya as it has been running for this. Issuing authority on the issuance of a certificate is not PD Pasar Jaya but agency in charge of publishing the SKBG. When referring to the Building Act SKBG publishing at the Department of Public Works, and when referring to the Law on Housing, the publishing SKBG by the Department of Housing. That way it is assured of legal certainty as mandated by state law, as well as the grand theory of Hans Kelsen. SKBG is way out proof of ownership of the store, which is very expensive because of the value it needs the necessary legal certainty regarding the right material.
\end{abstract}

Keywords: Droit De Preference, UMKM, Shops, Tanah Abang

\begin{abstract}
ABSTRAK
Sertifikat Hak Pemakaian Tempat Usaha (SHPTU) adalah bukti kepemilikan hak pemakaian tempat usaha (kios) di pasar yang dimiliki oleh Pedagang pasar. SHPTU memiliki nilai ekonomis yang cukup tinggi. Oleh karenanya diharapkan SHPTU dapat dijadikan jaminan kredit. SHPTU memiliki kesamaan unsur dengan sewa-menyewa sebagaimana pada pasal 1548 KUHPerdata. Karena SHPTU bukan hak kebendaan, maka SHPTU tidak dapat dijadikan jaminan dengan menggunakan pranata jaminan kebendaan. Tesis ini menggunakan metode penelitian normatif yuridis dengan menambahkan unsur empiris, dengan analisis data secara kualitatif. Dari hasil analisis dapat ditarik kesimpulan bahwa SHPTU bukan hak
\end{abstract}


kebendaan, namun mengingat SHPTU memiliki nilai ekonomis dan dapat dialihkan, maka diharapkan pemerintah dapat segera menjawab kebutuhan masyarakat (Para Pedagang Pasar) terhadap adanya suatu pranata jaminan yang dapat mengakomodir SHPTU kios sebagai jaminan kredit. Disebabkan dari rigiditas dari hukum kebendaan maka untuk melahirkan hak kebendaan atas tempat usaha atau SHPTU direkomendasikan untuk menggunakan kaedah yang terkandung dalam Pasal 48-49 tentang undang-undang Rumah Susun dengan menerbitkan Sertifikat Kepemilikan Bangunan dan Gedung (SKBG), dimana penerbitan sertifikat adalah sama antara Pemerintah Daerah dalam hal ini Dinas Pekerjaan Umum dan Dinas Perumahan, sementara pengelolaan tetap saja PD Pasar Jaya seperti yang sudah berjalan selama ini. Kewenangan penerbitan atas penerbitan sertifikat tidak pada PD Pasar Jaya akan tetapi lembaga yang berwenang atas penerbitan SKBG tersebut. Jika merujuk pada Undang-Undang Bangunan Gedung penerbitan SKBG pada Dinas Pekerjaan Umum, dan jika merujuk pada Undang-Undang Rumah Susun maka penerbitan SKBG oleh Dinas Perumahan. Dengan begitu maka terjamin kepastian hukum sebagaimana yang diamanatkan oleh Negara hukum, serta grand theory Hans Kelsen. SKBG merupakan jalan keluar bukti kepemilikan kios, karena nilai yang sangat mahal maka perlu diperlukan kepastian hukum tentang hak kebendaan.

Kata Kunci : Droit De Preference, UMKM, Kios, Tanah Abang.

\section{A. Pendahuluan}

Negara Indonesia dikenal sebagai Negara Hukum. Hal ini ditegaskan dalam UUD 1945 Pasal 1 ayat (3) yaitu Negara Indonesia adalah negara hukum. Negara hukum merupakan dasar Negara dan pandangan hidup setiap warga Negara Indonesia, serta Pancasila merupakan sumber dari semua tertib hukum yang berlaku di Negara Republik Indonesia.

Negara hukum, menempatkan hukum pada posisi yang tertinggi, kekuasaan harus taat pada hukum bukan hukum pada kekuasaan, apabila hukum tunduk pada kekuasaan, maka kekuasaan dapat membatalkan hukum, jadi dengan kata lain hukum dijadikan sebagai alat untuk membenarkan kekuasaan. Hukum harus menjadi tujuan untuk melindungi kepentingan rakyat.

Salah satu tujuan Negara Republik Indonesia dalam Pembukaan UUD 1945 sebagaimana disebutkan pada alinea ke empat : "melindungi segenap bangsa Indonesia dan seluruh tumpah darah Indonesia dan untuk memajukan kesejahteraan umum", yang menjadi landasan yuridis bagi tugas, wewenang dan tanggung jawab pemerintah negara Republik Indonesia untuk memberikan kepastian hukum dalam masyarakat yang dibutuhkan demi tegaknya ketertiban dan keadilan.

Ketidakpastian hukum akan menimbulkan kekacauan dalam kehidupan masyarakat, dan setiap anggota masyarakat akan saling berbuat sesuka hati serta bertindak main hakim sendiri. Keberadaan seperti ini dapat menjadikan kehidupan berada pada suasana kekacauan sosial. ${ }^{1}$ Peranan negara dalam mewujudkan kepastian hukum guna menciptakan perlindungan hukum yang adil sebagaimana diuraikan dalam beberapa Pasal dalam UUD 1945 antara lain sebagai berikut :

Pasal 1 ayat (3) : Negara Indonesia adalah negara hukum.

Pasal 27 ayat (1) : Segala warga negara bersamaan

kedudukannya di dalam hukum dan pemerintahan dan wajib menjunjung hukum dan pemerintahan itu

${ }^{1}$ M. Yahya Harahap, 2006, Pembahasan, Permasalahan dan Penerapan KUHAP, Edisi Kedua, Jakarta, Sinar Grafika, Hlm.76 
dengan tidak ada kecualinya.

Pasal 27 ayat (2) : Tiap-tiap warga negara berhak atas pekerjaan dan penghidupan yang layak bagi kemanusiaan.

Pasal 28 D ayat (1) : Setiap orang berhak atas pengakuan, jaminan, perlindungan, dan kepastian hukum yang adil serta perlakuan yang sama dihadapan hukum,

Pasal $28 \mathrm{G}$ ayat (1) : Setiap orang berhak atas perlindungan diri pribadi, keluarga, kehormatan, martabat, dan harta benda yang dibawah kekuasaannya, serta berhak atas rasa aman dan perlindungan dari ancaman ketakutan untuk berbuat atau tidak berbuat sesuatu yang merupakan hak asasi.

Pasal $28 \mathrm{H}$ ayat (1) : Setiap orang berhak hidup sejahtera lahir dan batin, bertempat tinggal, dan mendapatkan lingkungan hidup baik dan sehat serta berhak memperoleh pelayanan kesehatan.

Pasal 28 I ayat (4) : $\quad$ Perlindungan, pemajuan, penegakan, dan pemenuhan hak asasi manusia adalah tanggungjawab negara, terutama pemerintah.

Sehubungan hal tersebut, dalam rangka pemerataan pembangunan dengan tidak mengurangi pengawasan dari pemerintah pusat maka pemerintah membuat suatu sistem pengelolaan terpadu dan terstruktur dengan jelas yaitu dengan pembentukan perusahaan daerah yang telah diatur dalam Undang-Undang Nomor: 5 Tahun 1962 tentang Perusahaan Daerah maka merupakan suatu tuntutan bahwa perusahaan daerah harus memprotek segala urusan rumah tangganya dengan hukum yang berlaku agar dapat memberikan kepastian hukum.

Perusahaan Daerah (PD) Pasar Jaya sebagai salah satu Badan Usaha Milik Daerah Pemerintah Daerah Khusus Ibukota (DKI) Jakarta didirikan dengan maksud dan tujuan untuk melakukan pengurusan pasar dan fasilitas perpasaran lainnya dalam rangka pengembangan perekonomian daerah serta menunjang Anggaran Daerah dan pertumbuhan ekonomi nasional (Pasal 5 Peraturan Daerah Propinsi Daerah Khusus Ibukota Jakarta Nomor: 12 Tahun 1999). Perusahaan Daerah Pasar Jaya merupakan perusahaan daerah yang seluruh modalnya merupakan kekayaan daerah yang dipisahkan, maka dalam hal pengelolaan kekayaan milik daerah yang terdapat di pasar-pasar Perusahaan Daerah (PD) Pasar Jaya berlaku ketentuan Menteri Dalam Negeri Nomor; 153 Tahun 2004 tentang Pedoman Pengelolaan Barang Daerah yang dipisahkan Jo Peraturan Daerah Propinsi Daerah Khusus Ibukota (DKI) Jakarta Nomor; 17 Tahun 2004 tentang Pengelolaan Barang Daerah. Barang yang dipisahkan diartikan sebagi barang milik daerah baik barang bergerak ataupun barang tidak bergerak yang dikelola oleh badan usaha milik daerah.

Tanah serta bangunan pasar milik

Perusahaan Daerah Pasar Jaya merupakan kekayaan daerah yang dipisahkan dimana pengurusannya diserahkan untuk dikelola berdasarkan Peraturan Daerah Khusus Ibukota (DKI) Jakarta Nomor; 6 Tahun 1992 tertanggal 21 Juli 1992 tentang Pengurusan Pasar di Daerah Khusus Ibukota Jakarta. Dalam Peraturan Daerah DKI Jakarta Nomor; 6 Tahun 1992 disebutkan bahwa untuk 
dapat menggunakan tempat-tempat usaha harus mendapatkan ijin pemakaian tempat usaha secara tertulis dari Gubernur Kepala Daerah agar pemakaian tempat mempunyai hak memakai tempat di pasar (Pasal 1 huruf 9). Menurut Peraturan Daerah Nomor: 6 Tahun 1992 juga disebutkan bahwa Pemakai Tempat Usaha ialah orang atau badan hukum yang berdasarkan izin penghunian tempat mempunyai hak memakai tempat di pasar untuk memperdagangkan barang dan jasa (Pasal 1 huruf e). Berdasarkan uraian di atas, dapat dikatakan sebagai pemakai tempat usaha (pedagang) di pasar Perusahaan Daerah Pasar Jaya haruslah terlebih dahulu memiliki ijin berupa Surat Izin Pemakaian Tempat Usaha (SIPTU) adalah izin tertulis dari Direksi atas pemakaian tempat usaha di pasar.

Hal ini tidak sejalan dengan permasalahan yang ada di Perusahaan Daerah Pasar Jaya salah satunya adalah Tanah Abang, Tanah Abang merupakan tempat dagang yang sangat menggiurkan bagi para pedagang tekstil juga produk tekstil. Sebab berdagang, baik secara grosir maupun ritel, di Tanah Abang sangat prospektif dan mendapatkan untung berlipat. Tidak heran bila kios selalu menjadi incaran pedagang. Adapun pasar Tanah Abang terbagi menjadi beberapa blok, yakni A, B, C, D, E, F, G, AA, BB, dan CC. Namun tidak semua blok di Tanah Abang yang menjadi incaran pedagang. Posisi blok menjadi sangat menentukan untung atau tidak.

Namun disisi lain, para pengusaha / pribumi mengeluhkan dengan adanya biaya tarif yang dijual begitu besar dengan ukuran yang minimalis, salah satu contoh Kios/Toko yang dijual ${ }^{2}$ adalah sebagai berikut:

- Kios / Toko (posisi badan)

- Harga Jual:

\footnotetext{
${ }^{2}$ http://www.jualsewakios.com/tag/tanah-abang/, diakses pada tanggal 16 Agustus 2016.
}

○ Ukuran luas: 10 m2 (Hook \& Badan)

- Lokasi: Pasar Tanah Abang Blok B, los G, No.119-120 Jakarta Pusat (hall depan pintu masuk lobby)

- Harga: Rp 5.300.000.000.-

○ Ukuran luas : 9 m2 (Hook \& Badan)

- Lokasi: Pasar Tanah Abang Blok B, los G, No.35-36 Jakarta Pusat (posisi diHall)

- Harga: Rp 3.100.000.000,-

- Ukuran luas: $\mathbf{5} \mathbf{~ m 2}$ (Badan)

- Lokasi: Pasar Tanah Abang Blok B,Los D,No.49,Lantai 2 Jakarta Pusat (posisi di Bunderan sebelah lift)

- Harga: Rp 1.600.000.000,-

Untuk mengetahui permasalahan tersebut perlu adanya pengembangan Droit De Preference yang melingkupi keterbatasan pemahaman instansi pemerintah mengenai hukum jaminan yang ada terhadap kepemilikan tempat usaha yang dimiliki pedangang khususnya Pasar Pemerintah dalam hal ini Pasar Tanah Abang.

Dan pembeli tidak memiliki pemahaman tentang hak yang timbul dari transaksi jual beli kios pada dasaranya yang telah mereka sediakan, misal $2 \times 3 \mathrm{~m}^{2} \mathrm{Rp} .700$ juta nilai ekonomi yang sangat tinggi. ${ }^{3}$ Maka dari itu praktik Perbankan dan Kantor Notaris ditemukan banyak yang belum bisa memahami tentang hal itu, hal ini disebabkan kurang pemahaman kepastian hukum tentang Hak Guna Bangunan sebagimana diatur dalam UU Bangunan dan Gedung yang dikatakan bahwa bangunan gedung dapat dimiliki oleh orang perorangan dengan kepemilikan sertifikat akan tetapi ternyata banyak sekali permintaan dari pedagang / pengusahan, UMKM. Sehingga pedagang usaha UMKM harus mencari alternatif

\footnotetext{
${ }^{3}$ Hadi Wijaya, http://www.telingamata.com/kios-ditanah-abang-lebih-mahal-dari-tokyo-dan-new-york/ di akses pada tanggal 14 Agustus 2016
} 
jaminan berupa aset lain atas fasilitas pendanaan bank tersebut. Dan tidak banyak pengusaha pedagang UMKM yang mempunyai aset lain terutama pedagang pengusaha UMKM pribumi. dari hasil penjualan tempat usaha dari pasar pemerintah kenapa tidak bisa dijadikan jaminan atas fasilitas pembiayaan Bank, akan tetapi mencari alternatif jaminan aset, seperi rumah, tanah, mobil. Adanya pembelian kios yang sangat mahal para pengusaha pedagang UMKM tidak bisa menikmati mutlak hak atas asas kebendaan tersebut.

Berdasarkan Survei hasil dari wawancara $^{4}$ penulis dengan salah satu bank pemerintah yaitu Bank BRI Cabang Cut Mutia Jakarta, selaku staf administrasi kredit Bapak Dani Suhendro, SE. bahwa hak yang dipegang oleh pemilik tempat usaha terutama pasar pemerintah tanah abang jakarta adalah Sertifikat Hak Pemakai Tempat Usaha (SHPTU) yang mempunyai jangka waktu 20 tahun dan bukti hak tersebut tidak dapat didaftarkan secara fidusia maupun hak tanggungan.

Adapun optimalisasi peran pemerintah karena selama ini pemerintah sebagai apa? Pegawai petugas pasar atau pengawas petugas pasar atau dinas pasar perannya seperti apa? Apakah mereka dapat memberikan suatu kepastian hukum daripada kepemilikan tempat usaha, selama ini apakah berupaya pemerintah dapat memberikan hak yang lebih luas, sehingga dinas pasar dapat meberikan model baru tentang persertifikatan, sehingga identifikasi masalahnya adalah model persertifikatan pengelolaan bangunan dan gedung atau asas pemisahan horizontal, sehingga pemerintah dapat mengisi kekosongan hukum dengan membuat aturan persertifikat hak atas kios sejalan dengan hak bangunan dan gedung jadi sangat membantu bagi para pedagang pasar pemerintah untuk mendapatkan fasilitas

\footnotetext{
${ }^{4}$ Wawancara pada hari Kamis, tanggal 15 September 2016, di Bank BRI Cabang Cut Mutia Jakarta, staf administrasi kredit, Dani Suhendro, SE.
}

kredit kuangan pada bank terutama pada pemerintah bagaimana mereka mensosialisasikan tentang bagaiamana model kepemilikan sepertihalnya sewa kios ada tidak kepemilikan sertifikat hak sewa dalam jangka waktu 5 tahun atau 10 tahun seperti leasehold dan freehold di singapura. Adapun tenor residential properti di Singapura yang lazim yaitu 99 tahun leasehold, 999 tahun leasehold, freehold. Jika dikaitkan dengan lokasi, apartemen singapura dengan tenor 99 tahun leasehold biasa lebih strategis dan dekat dengan Mass Rapid Transit (MRT). ${ }^{5}$

Jadi pemerintah dapat membuka akses keuangan kreditan kepada pengusaha-pengusaha karena pedagang sebagian besar adalah pedagang pribumi, ketika pemerintah tertuju pada perbankan melalui Bank Indonesia bagaimana bankbank di Indonesia memberikan sosialisasi untuk memikirkan permasalahan ini dan bekerjasama dengan Kementerian Hukum dan Hak Asasi Manusia (KEMENKUMHAM) RI. dapat menerima kios ini, karena dapat diterimanya kios ini sebagai jaminan sehingga bank-bankpun bisa mengerti kios tersebut bisa dijaminkan dan KEMENKUMHAM dapat membuka model baru sehingga tidak lagi terjadi persoalan tersebut, kantor notaris dan dinas pasar berkomunikasi dengan pemerintah agar bisa menjelaskan bahwa kios tersebut bisa dijaminkan ke perbankan.

Berdasarkan hal tersebut, pengusahapengusaha pribumi yang tidak mempunyai aset tidak mampu membeli kios tersebut, upaya yang dilakukan dijaminkan ke bank sebagai jaminan atau fasilitas kredit dari bank dengan menggunakan Surat Izin Pemakaian Tempat Usaha (SIPTU), akan tetapi pada kenyataannya SIPTU tersebut tidak bisa dijaminkan.

\footnotetext{
${ }^{5}$ http://www.apartemensingapore.info/cara-membeliapartemen-di-singapura/\#.WKD-qvlyfDc diakses pada tahun 2014 Huttons Asia Pte Ltd
} 
Dalam Konstruksi hukum Jual beli terdapat beberapa hak dengan sifat publisitas, yang diantaranya menjunjung hak-hak kebendaan, droit de suite (hak kebendaan yang mengikuti, termasuk kenikmatan dan kewenangan terhadap benda), droit de preference (hak didahulukan dalam sistem hukum jaminan), dan droit de levering, menurut pendapat Martin Roestamy bahwa yang dapat dialihkan dalam bentuk peralihan benda dalam sistem hukum keperdataan dalam ruang lingkup benoemde verbintenis sebagaimana diatur dalam KUHPerdata, menjadi objek peralihan, apakah itu jual beli, hibah, tukar menukar, inbreng, maupun warisan). Oleh karena itu, sifat publisitas berkaitan erat dengan sistem pendaftaran kebendaan. ${ }^{6}$

Droit de preference merupakan salah satu ciri dari jaminan kebendaan. Droit de preference yang artinya hak kebendaan yang mula terjadi akan lebih diutamakan daripada yang terjadi kemudian atau sering juga disebut asas prioritas. ${ }^{7}$ Jika debitur melakukan wanprestasi maka dalam jaminan kebendaan kreditur mempunyai hak didahulukan (preferent) dalam pemenuhan piutangnya di antara kreditur-kreditur lainnya dari hasil penjualan harta benda milik debitur. Contoh droit de preference dalam pengaturan jaminan kebendaan misalnya : Gadai, Fidusia dan Hak Tanggungan.

Hak kebendaan merupakan hak-hak kekayaan yang mempunyai ciri-ciri sebagai berikut: bersifat absolut (bisa ditujukan kepada semua orang pada umumnya), yang lahir lebih dulu mempunyai kedudukan yang lebih tinggi dan melekat terhadap suatu benda

\footnotetext{
${ }^{6}$ Martin Roestamy, 2009, Hukum Jaminan Fidusia (Perlindungan Hukum Kepada Kreditur Pemegang Jaminan Fidusia Benda tidak Terdaftar), Bogor UNIDA Press, Hlm. 43.

${ }^{7}$ Frieda Husni Hasbullah, 2005, Hukum Kebendaan Perdata: Hak-Hak yang Memberi Kenikmatan, Hlm. 17.
}

tertentu $^{8}$. Oleh sebab itu suatu hak kebendaan merupakan suatu hak yang bisa dituntut terhadap setiap orang yang berkaitan dengan benda yang dihaki oleh seseorang, karena hak kebendaan itu sendiri ialah hak yang mengikuti kemanapun benda itu berada droit de suite.

Hak kebendaan yang mengikuti kemanapun benda tersebut berada mempunyai sifat yang bertingkat dalam artian bahwa ada suatu hak kebendaan yang tingkatannya lebih tinggi dari hak kebendaan yang lainnya dan begitu pula sebaliknya bahwa ada suatu kebendaan yang tingkatnya lebih rendah dari hak kebendaan yang lainnya. Tinggi rendahnya tingkat hak kebendaan tersebut akan berimplikasi tentang luasnya cakupan hak pada suatu kebendaan tertentu. Misalnya ada suatu hak kebendaan yang hanya memberikan kepada orang yang mempunyai hak kebendaan tersebut sekedar menguasainya atau menggunakan manfaat kebendaan tersebut, dan ada juga suatu hak kebendaan yang selain memberikan hak untuk menguasai benda tersebut dan menggunakan benda tersebut kepada si pemegang hak kebendaan tersebut memberikan juga hak untuk mengalihkan kepemilikan dari benda tersebut.

Hak atas suatu kebendaan dalam hukum common law, dikaji dalam law of property. Secara etimologi, law of property dapat diartikan sebagai hukum yang mengatur tentang property. Berkaitan dengan pengertian dari property tersebut $C . \quad R$. Noyes menyebutkan bahwa

"the term of property may be defined to be the interest which can be acquired in external object or things. The things themselves are not in a true sense, property, but they constitute its foundation and material, and the idea of property

\footnotetext{
${ }^{8}$ J. Satrio, 1999, Perikatan Pada Umumnya, Bandung
} : Alumni, Hlm. 6-11. 
springs out the connection or control, or interest which, according to law, may acquired in them or over them"

Dari pendapat yang dikemukakan oleh Noyes tersebut maka dapatlah dimengerti bahwa yang dimaksud property adalah suatu kepentingan yang bisa diberikan atas suatu objek atau benda. Benda-benda tersebut sendiri bukanlah dalam artian sesungguhnya tetapi benda-benda tersebut menentukan pondasi atau material dan ide dari property yang memunculkan hubungan atau kontrol atau kepentingan yang dapat diberikan oleh hukum atas benda-benda tersebut. Sedangkan C.B Macpherson menyebutkan bahwa Property bukan tentang benda itu sendiri melainkan mengenai hak atas benda tersebut. Dari pendapat kedua sarjana tersebut maka bisa dipahami bahwa property bukanlah berbicara mengenai suatu kebendaan tertentu melainkan berbicara tentang hak yang berada di atas benda tersebut, dan hak dalam hal ini juga diartikan sebagai suatu kepentingan. Kepentingan umum ialah termasuk kepentingan bangsa dan negara juga kepentingan bersama dari rakyat, dengan memperhatikan segi-segi sosial, politik, psikologis atas dasar asasasas Pembangunan Nasional dengan mengindahkan Ketahanan Nasional serta Wawasan Nusantara.

Berdasarkan uraian tersebut diatas penulis tertarik untuk membuat kajian mengenai bagaimana konsep pengembangan Droit de Preference yang bisa diterapkan dan diimplementasikan bagi Kepemilikan Tempat Usaha Pada Pasar Tanah Abang Jakarta dan bagaimana optimalisasi peran lembaga pemerintah dalam pelaksanaan Kepemilikan Tempat Usaha pada Pasar Tanah Abang.

${ }^{9} \mathrm{C}$. R. Noyes, 1936, The Institution of Property, New York, Hlm. 357.

\section{B. Konsep Pengembangan Model Droit de Preference yang Dapat Diterapkan dan Diimplementasikan Bagi Kepemilikan Tempat Usaha Pada Pasar Pemerintah Di Pasar Tanah Abang}

Adanya sebuah perubahan masyarakat harus diikuti oleh perubahan hukum. ${ }^{10}$ Hukum berkembang sesuai dengan perkembangan kebutuhan masyarakat. Perubahan masyarakat dalam bidang hukum jaminan harus berlangsung secara teratur dan diikuti dengan pembentukan hukum jaminan fidusia berjalan dari kebiasaan kemudian diakui dalam yurisprudensi dan akhirnya ditetapkan dalam undang-undang tersendiri.

Teori yang tepat digunakan sebagai pendukung teori perubahan masyarakat adalah teori sistem. Lawrerence M. Friedman berpendapat, Suatu sistem hukum terdiri dari 3 unsur yaitu: Struktur (structure), substansi (substance), dan budaya hukum (legal Culture). ${ }^{11}$

Suatu sistem merupakan kumpulan asas-asas yang terpadu, yang merupakan landasan, di atas mana dibangun tertib hukum. ${ }^{12}$ Selain itu, Hukum Bangunan pertama kali digagas oleh Djuhaendah Hasan dalam disertasinya Lembaga Jaminan ${ }^{13}$ yang kemudian dikembangkan oleh Martin Roestamy dengan mengembangkan konsep hukum bangunan. ${ }^{14}$ Djuhaendah Hasan

\footnotetext{
${ }^{10}$ Satjipto Rahardjo, Hukum dan Masyarakat, Angkasa: Bandung, 1984, Hlm. 102.

${ }^{11}$ Lawrence M. Friedmann, American Law, W.W Norton dan Company: New York London, 1984, Hlm. 5-6.

${ }^{12}$ Mariam Darus Badrulzaman, 1983, Mencari Sistem Hukum Benda Nasional, Alumni: Bandung, Hlm. 15.

${ }^{13}$ Djuhaendah Hasan, Lembaga Jaminan Kebendaan Bagi Tanah Dan Benda Lain Yang Melekat Pada Tanah Dalam Konsepsi Penerapan Asas Pemisahan Horisontal: Suatu Konsep Dalam Menyongsong Lahirnya Lembaga Hak Tanggungan (Citra Aditya Bakti, 1996).

${ }^{14}$ Martin Roestamy, Kepastian Hukum Atas Kepemilikan Rumah Dan Bangunan Gedung Oleh Investor Asing Dikaitkan Dengan Asas Nasionalitas Dalam Sistem Huum Pertanahan Indonesia, yang
} 
bermaksud mengembangkan hukum benda di atas tanah sebagai jaminan, dengan begitu ruang lingkup jaminan baik hak tanggungan dan fidusia, dimaksudkan ke depan benda-benda di atas tanah memiliki perspektif hukum kebendaan dalam hal penjaminan hutang pada bank. Sedangkan Roestamy langsung kepada mekanisme sistem hukum benda, dengan sifatnya yang rigid, berbekal dari amanah pasal 12 Undangundang Bangunan Gedung Nomor 28 tahun 2002, yang menyebutkan bahwa ada peluang untuk mewujudkan bangunan sebagai benda yang berdiri sendiri yang terpisah dari tanah, karena selama ini telah diikat oleh Undang-Undang Nomor 42 tahun 1999 Tentang Jaminan Fidusia serta KUHPerdata pasal 500, serta dikaitkan pasal 4 ayat 4 undang-undang hak tanggungan (UUHT). Hukum Bangunan dimaksudkan ingin memberikan kedudukan tersendiri sebagai benda yang terlepas dari tanah sehingga terbebas dari rezim Hukum Tanah. Benda yang dimaksud bersifat mandiri yang ingin penulis dalam tulisan ini, untuk dapat memiliki sifat publisitas, dapat pula menjunjung hak-hak kebendaan, droit de suite (hak kebendaan yang mengikuti, termasuk kenikmatan dan kewenangan terhadap benda), droit de preference (hak didahulukan dalam sistem hukum jaminan), dan droit de levering (sebagaimana Roestamy, yang dapat dialihkan dalam bentuk peralihan benda dalam sistem hukum keperdataan dalam ruang lingkup benoemde verbintenis sebagaimana diatur dalam KUHPerdata, menjadi objek peralihan, apakah itu jual beli, hibah, tukar menukar, inbreng, maupun warisan). Oleh karena sifat publisitas berkaitan erat dengan sistem pendaftaran kebendaan, sebagaimana pendaftaran tanah, maka pendaftaran benda akan masuk dalam rezim pendaftaran hak. ${ }^{15}$

dipertahankan dalam sidang terbuka, pada tanggal 12 September 2008 di Universitas Padjadjaran.

${ }^{15}$ Martin Roestamy, Hukum Jaminan Fidusia (Perlindungan Hukum Kepada Kreditur Pemegang
Kedua pikiran di atas akan dikembangkan dalam penelitian ini yang penulis akan buat dimana pendaftaran hak kebendaan berupa Hak Milik Kios/Los hendaklah dipisahkan dari pendaftaran atas tanah yang dilakukan oleh instansi yang dibentuk oleh pemerintah, dapat saja instansi tersebut pada tatanan otonomi daerah di Kabupaten/Kota. Sehingga Kios/Los dapat dijaminkan oleh pedagang dengan harga yang beranekaragam kepada lembaga keuangan dalam hal ini perbankan.

Sebagaimana terjadi di Perusahaan Daerah (PD) Pasar Jaya khususnya Pasar Tanah Abang Jakarta yang di atasnya terdapat los/kios yang terpisah dari tanah kepemilikannya, akan tetapi sama sekali tidak terdaftar. Menurut penulis apabila dihubungkan antara kios/los tersebut memiliki nilai ekonomis, tetapi sayangnya tidak dapat dijaminkan, karena tidak memiliki alas hak yang kuat sehingga bank berkeberatan menerimanya sebagai jaminan.

Pendaftaran hak milik unit Kios/Los terlepas dari tanah adalah sebagai konsepsi hukum bangunan yang terusannya menjadi hukum properti, dengan segala konskuensi dan keterkaitan pengelolaan properti, pendaftaran, serta hak-hak yang berhubungan dengan kebendaan yang menjadi jaminan seperti fidusia atau hukum jaminan lainnya.

Hukum jaminan yang dapat dipergunakan dari kepemilikan bangunan gedung atau perumahan yang terpisah

Jaminan Fidusia Benda tidak Terdaftar), Bogor UNIDA Press, 2009. Hlm 43. Untuk menciptakan kepastian hukum tentang hak kebendaan, maka ke depan Indonesia harus memiliki Pusat Pelayanan Pendaftaran Hukum Hak Kepemilikan di seluruh Kabupaten/Kota. Agar setiap benda memiliki identifikasi dan sifat publisitas maka pendaftaran hak kepemilikan atas semua benda yang ada menjadi keharusan. Dengan pendaftaran itu, tidak ada lagi benda yang tidak terdaftar, termasuk diant aranaya akan tetapi tidak terbatas pada benda-benda yang berkaitan dengan unit kios dan pasar-pasar tradisional yang dikelola oleh pemerintah agar rakyat memiliki tanda bukti hak kemilikan dari tempat usahanya yang selama ini masih sangat tidak akuntabel. 
dari tanah pada dasarnya perbankan dapat menggunakan fidusia, dimana asas publisitas dari pendaftaran fidusia dapat dilakukan pada kantor pendaftaran fidusia untuk kemudian hak-hak jaminan atas fidusia dapat memiliki titel eksekutorial dan kekuatan hukum sempurna yang tidak dapat dibanding dan dikasasi sehingga pengembangan pendaftaran bangunan sebagai objek pendaftaran fidusia tidak dilaksanakan secara kasuistis oleh kantor-kantor notaris yang mengerti hukum bangunan, akan tetapi berkembang menjadi domain umum, sehingga dapat bermanfaat bagi para pemilik bangunan, apakah bangunan di atas hak milik tanah bersama yang merupakan tapak bangunan los/kios yang akan diulas dalam pengembangan model asas droit de preference, atau bangunan di atas tanah milik pemerintah sebagaimana Sertifikat Kepemilikan Bagunan Gedung (SKBG) yang tertuang dalam pasal 48 Undang-Undang Nomor 20 tahun 2011 untuk kepemilikan rumah bagi MBR. Dapat juga sebagaimana praktik di masyarakat bahwa pendaftaran bangunan kios-kios pembangunan pemerintah seperti proyek Tanah Abang.

Menurut Hans kelsen mengartikan hukum ialah tata aturan (rule) sebagai suatu sistem aturan-aturan (rules) tentang perilaku manusia. Dengan demikian hukum tidak menumpuk pada satu aturan tunggal (rule) tetapi seperangkat aturan (rules) yang memiliki satu kesatuan sehingga dapat dipahami sebagai suatu sistem, konsekuwensinya adalah tidak mungkin memahami hukum jika hanya memperhatikan satu aturan saja. ${ }^{16}$

$$
\text { Menurut Satjipto } \text { Raharjo }^{17}
$$

menyatakan bahwa pemikiran hukum perlu kembali pada filosofis dasarnya, yaitu hukum untuk manusia. Dengan filosofis tersebut, maka manusia menjadi penentu dan juga titik orientasi hukum.

\footnotetext{
${ }^{16}$ Jimly Asshidiqie dan Ali Safa`at, 2006, Teori Hans Kelsen tentang Hukum, Jakarta, Sekjen dan Kepaniteraan MK-RI, Hlm. 13

${ }^{17}$ Satjipto Rahardjo, 2006, Menggagas Hukum Progresif Indonesia, Yogyakarta : Pustaka Pelajar.
}

Hukum memiliki tugas melayani manusia, dan bukan sebaliknya. Oleh sebab itu, hukum itu bukan merupakan institusi yang lepas dari kepentingan manusia. Mutu hukum ditentukan oleh kemampuannya untuk mengabdi pada kesejahteraan manusia. Ini menyebabkan hukum progresif menganut "ideologi" : Hukum yang pro-keadilan dan Hukum yang Prorakyat.

Bagi hukum progresif, proses perubahan tidak lagi berpusat pada peraturan, tetapi pada kreativitas pelaku hukum mengaktualisasikan hukum dalam ruang dan waktu yang tepat. Para pelaku hukum progresif bisa melakukan perubahan dengan melakukan pemaknaan yang kreatif terhadap peraturan yang ada, tanpa harus menunggu perubahan peraturan (changing the law). Peraturan buruk tidak harus menjadi penghalang bagi para pelaku hukum progresif untuk menghadikarkan keadilan untuk rakyat dan pencari keadilan, karena mereka bisa melakukan interprestasi secara baru setiap kali terhadap suatu peraturan. Untuk itu agar hukum dirasakan manfaatnya, maka dibutuhkan jasa pelaku hukum yang kreatif menterjemahkan hukum itu dalam kepentingan-kepentingan sosial yang memang harus dilayaninya.

Berdasarkan teori ini, keadilan tidak bisa secara langsung ditemukan lewat proses logis-formal. Keadilan justru didapat lewat institusi, karenanya, argumentargumen logis formal "dicari" sesudah keadilan ditemukan untuk membingkai secara yuridis-formal keputusan yang diyakini adil tersebut. Oleh sebab itu konsep hukum progresif, hukum tidak mengabdi bagi dirinya sendiri, melainkan untuk tujuan yang berada di luar dirinya.

Selain itu, menurut Mochtar Kusumaatmadja $^{18}$ mengemukakan Hukum merupakan suatu alat untuk memelihara ketertiban dalam masyarakat. Mengingat fungsinya sifat hukum, pada dasarnya adalah konservatif artinya, hukum bersifat

\footnotetext{
${ }^{18}$ Mochtar Kusumaatmadja, 2002, Konsep-Konsep Hukum Dalam Pembangunan (Kumpulan Karya Tulis) Penerbit Alumni, Bandung, Hlm. 14
} 
memelihara dan mempertahankan yang sudah tercapai. Fungsi demikian diperlukan pada setiap masyarakat, termasuk masyarakat yang sedang membangun, karena di sini pun ada hasilhasil yang harus dipelihara, dilindungi dan diamankan. Akan tetapi, masyarakat yang sedang membangun, yang artinya masyarakat yang sedang berubah cepat, hukum tidak cukup memiliki fungsi demikian saja.

Dalam pengembangannya konsep hukum pembangunan ini akhirnya diberi nama oleh para murid-muridnya dengan "Teori Hukum Pembangunan". ${ }^{19}$ Ada 2 (dua) aspek yang melatarbelakangi kemunculan teori hukum ini, yaitu: Pertama, ada asumsi bahwa hukum tidak dapat berperan bahkan menghambat perubahan masyarakat. Kedua, dalam kenyataan di masyarakat Indonesia sudah terjadi perubahan alam pemikiran masyarakat ke arah hukum modern. Oleh karena itu, Mochtar Kusumaatmadja ${ }^{20}$ mengemukakan tujuan pokok hukum bila direduksi pada satu hal saja adalah ketertiban yang dijadikan syarat pokok bagi adanya masyarakat yang teratur. Tujuan lain hukum adalah tercapainya keadilan yang berbeda-beda isi dan ukurannya, menurut masyarakat juga jamannya. Selanjutnya untuk mencapai ketertiban diusahakan adanya kepastian hukum dalam pergaulan manusia di masyarakat, karena tidak mungkin manusia bisa mengembangkan bakat dan kemampuan yang diberikan Tuhan kepadanya secara optimal tanpa adanya kepastian hukum dan ketertiban.

Pengertian lain mengenai hukum, disampaikan oleh Martin Roestamy yang mengartikan hukum adalah seperangkat aturan dan ketentuan yang mengatur tata tertib kehidupan, masyarakat juga negara

${ }^{19}$ Lili Rasjidi dan Ida Bagus Wiyasa Putra, 2003, Hukum Sebagai Suatu Sistem, Penerbit: CV. Mandar Maju, Bandung, Hlm. 182.

${ }^{20}$ Mochtar Kusumaatmadja, Fungsi dan Perkembangan Hukum dalam Pembangunan Nasional, Penerbit Bina Cipta, Bandung, tanpa tahun, Hlm. 2-3. dengan tujuan untuk mencapai keadilan, ketertiban umum, perdamaian dan kesejahteraan. $^{21}$

Dalam kehidupan bermasyarakat sedikit banyak berjalan dengan tertib dan juga teratur ini tidak lepas dari adanya dukungan oleh adanya suatu tatanan. Karena dengan adanya tatanan inilah kehidupan menjadi tertib, sehingga hukum merupakan bagian integral dari kehidupan manusia. Hukum mengatur dan menguasai manusia dalam kehidupan manusia dalam kehidupan bersama. Maka hal tersebut perlindungan hukum sangat dibutuhkan bagi manusia demi perkelakuan di masyarakat untuk memberikan suatu keadilan bagi masyarakat. Sehingga perlindungan hukum adalah perlindungan akan harkat dan martabat, serta pengakuan terhadap hak-hak asasi manusia yang diikuti oleh subjek hukum dalam negara hukum, berdasarkan ketentuan hukum dari kesewenangan. $^{22}$

Sertifikat Hak Pemakaian Tempat Usaha (SHPTU) adalah bukti kepemilikan hak pemakaian tempat usaha (kios) di pasar yang dimiliki oleh Pedagang pasar. Keberatan bank untuk menerima SHPTU sebagai jaminan kebendaan memiliki alasan yang kuat, sebab SHPTU bukanlah hak kebendaan melainkan hak perorangan. Mengingat SHPTU tidak diatur dalam Buku II KUHPerdata, SHPTU bukan merupakan bukti kepemilikikan kios serta SHPTU lahir dari perjanjian antara pedagang pasar, developer dan PD Pasar Jaya.

Lebih lanjut SHPTU juga memiliki kesamaan unsur dengan sewa-menyewa sebagaimana pada pasal 1548 KUHPerdata. Karena SHPTU bukan hak kebendaan, maka SHPTU tidak dapat dijadikan jaminan dengan menggunakan pranata jaminan kebendaan.

\footnotetext{
${ }^{21}$ Martin Roestamy, Metodologi Penelitian Hukum, Bahan Matakuliah MPH, Sekolah Pascasarjana Universitas Djuanda Bogor, 26 Januari 2015, Hlm. 6. ${ }^{22}$ Philipus M. Hadjon, 1987, Perlindungan Hukum Bagi Masyarakat Indonesia, Jakarta : Bina Ilmu, Hlm. 105
} 
Perlindungan hukum dalam pembagian dalam hak benda sistem hukum adat didasarkan pada asas pemisahan horizontal. Dimana terdapat pemisahan antara tanah dan setiap obyek yang berada di atasnya. Sehingga pembagian tanah dan bukan tanah dalam sistem hukum adat, selalu diletakkan dalam hubungan antara tanah dengan obyek benda yang berada di atasnya. Asas Pemisahan Horizontal mengandung makna bahwa pemilik tanah tidak dengan sendirinya meliputi pemilikan bangunan dan tanaman yang ada di atasnya. siapa yang membangun dan siapa yang menanam, dialah pemilik bangunan yang dibangunnya dan dialah yang berhak atas hasil tanaman yang ditanamnya. ${ }^{23}$

Pemberian tanda bukti hak atas kepemilikan satuan rumah susun, pada dasarnya diberikan untuk dan dalam rangka perlindungan hukum serta jaminan kepastian hukum bagi subyek hukum untuk menikmati hak kebendaan yang melekat pada bangunan rumah atau gedung dalam hal ini unit satuan rumah susun. Sebagai sebuah hak kebendaan, hak atas bangunan gedung atau rumah, maka di dalamnya melekat semua sifat dari hak kebendaan. Salah satu sifat dari hak kebendaan terkait dengan Pemberian tanda bukti hak atas kepemilikan satuan rumah susun ialah bahwa hak kebendaan merupakan hak mutlak, yaitu hak yang dapat dipertahankan kepada siapapun yang dibedakan dari hak perorangan yang hanya dapat dipertahankan terhadap seseorang yang memiliki hubungan hukum dengan subyek hukum tersebut. ${ }^{24}$ Salah satu karakteristik utama dari sifat hak mutlak, bahwa hak kebendaan tersebut mengikat umum/kepada siapapun, dapat dialihkan dan dibebankan.

Peran negara dalam proses pembentukan sertifikat hak bangunan gedung atau rumah ekuivalen dengan konsep negara menaruh kehendaknya di dalam proses pengumuman (asas publisitas) dan penerbitan sertifikat. Setiap pengabaian atau setiap tindakan yang menganggu

\footnotetext{
${ }^{23}$ Ibid, Hlm. 213.

${ }^{24}$ Sri Soedewi Masjchoen Sofwan, Hukum Perdata: Hukum Benda, Liberty, Yogyakarta, Hlm. 25.
}

kenikmatan pemegang hak bangunan gedung atau rumah, akan mendapatkan reaksi dari negara yakni berupa sanksi. Sanksi terhadap gangguan kenikmatan, dapat berbentuk sanksi pidana (delik harta benda), perdata dan administrasi. Sehingga pembentukan sertifikasi atas hak bangunan gedung dan rumah, menjadi instrumen yang efektif untuk mencapai kepastian hukum terkait dengan kepemilikan hak bangunan gedung dan rumah.

Negara melalui organ pelaksananya harus mampu melaksanakan kewenangan berdasarkan peraturan perundang-undangan dan sikap tindak administrasi negara yang terjabarkan dalam perencanaan, kelembagaan dan kebijakan atas potensi sumber daya yang ada berlandaskan pada asas penegakkan peraturan hukum dan asasasas sikap tindak administrasi negara yang baik. $^{25}$

Hak kebendaan atas HMSRS yang dibangun diatas HGB merupakan pengembangan dari konsep pembentukan Sertifikat Kepemilikan Bangunan Gedung (SKGB) yang saat ini sudah digunakan dalam dalam sistem hukum rumah susun, akan tetapi masih terbatas pada rumah susun yang dibangun diatas tanah pemerintah (baik instansi pusat maupun daerah) dan tanah wakaf.

Pembatasan terhadap penerbitan SKBG yang ada saat ini antara lain:

a. SKBG hanya diberikan kepada pemilik rumah susun khusus atau rumah susun umum yang berdiri tanah sewa atas tanah Barang Milik Negara atau tanah wakaf.

b. SKBG tidak diberikan kepada pemilik bangunan rumah susun yang telah memiliki sertifikat Hak Milik Atas satuan Rumah Susun.

c. SKBG tidak diberikan kepada pemilik rumah susun yang berdiri diatas tanah dengan status Hak milik, Hak Guna Bangunan, Hak pakai, karena dengan status hak atas tanah

\footnotetext{
${ }^{25}$ Winahyu Erwiningsih, Hak Menguasai Negara Atas Tanah, Universitas Islam Indonesia, Fakultas Hukum Program Pascasarjana, Total Media, 2009, Hlm. 6-7 dan 213.
} 
tersebut maka yang diterbitkan adalah bukti pemilikan satuan Rumah Susun berikut tanah bersamanya yang terkandung dalam NPP yaitu SHM Sarusun.

Sekiranya pemberian SKBG diberlakukan untuk setiap Kios/Los yang dibangun diatas tanah milik pemerintah, tanah wakaf maupun tanah dengan bukti hak lainnya maka akan memberikan kepastian hukum dan perlindungan kepada hak-hak dari pemilik unit los karena berlakunya asas pemisahan horisontal. Jika SHPTU menjadi objek hak tanggungan sebagaimana dikemukakan dalam penjelasan sebelumnya maka SKBG adalah objek fidusia yang pendaftaranya lebih murah dan sederhana yaitu dikantor pendaftaran fidusia di bandingkan dengan pengikatan hak tanggungan di Kantor Badan Pertanahan.

\section{Optimalisasi Peran Pemerintah Dalam Pelaksanaan Kepemilikan Tempat Usaha pada Pasar Pemerintah di Pasar Tanah Abang.}

Perusahaan Daerah (PD) Pasar Jaya mengeluarkan Keputusan Direksi Nomor: 450 Tahun 2003 Tentang Pelaksanaan Peraturan Daerah Khusus Ibukota (DKI) Jakarta Nomor; 6 Tahun 1992 Tentang Pengelolaan dan Pengembangan Pasar. Di dalam Peraturan Daerah Khusus Ibukota (DKI) Jakarta Nomor: 6 Tahun 1992 disebutkan mengenai Hak Pemakaian Tempat Usaha sebagai ijin untuk memakai tempat usaha di kios yang terdapat pada pasar di Jakarta. Hal ini terdapat pada Pasal 1 huruf f Disebutkan "Pemakai Tempat Usaha adalah orang atau badan hukum yang berdasarkan ijin penghunian tempat mempunyai hak memakai tempat di pasar untuk memperdagangkan barang dan jasa". Hak pemakaian tempat usaha sebagaimana diatur dalam Pasal 9 ayat 2 Peraturan Daerah Khusus Ibukota (DKI) Jakarta Nomor: 6 Tahun 1992 Tentang
Pengelolaan dan Pengembangan Pasar merupakan suatu hak untuk memakai atas kebendaan berwujud dari tempat usaha pada bangunan pasar yang dimiliki dan dapat dialihkan serta dapat dijadikan jaminan kredit baik kredit modal kerja maupun kredit pemilikan Hak Pemakaian Tempat Usaha. Hal ini sesuai dengan Pasal 10 ayat 1 dan ayat 2 Keputusan Direksi Peraturan Daerah Pasar Jaya Nomor: 450 Tahun 2003 yaitu: "Pemakai tempat usaha dapat menjaminkan Hak Pemakaian Tempat Usahanya yang berapa Sertiflkat Hak Pemakaian Tempat usaha dan surat perjanjian pemakaian tempat usaha untuk memperoleh Kredit bank setelah terlebih dahulu mendapat ijin tertulis dari Direksi atau pejabat yang ditunjuk".

Dengan demikian, Undang-Undang Jaminan Fidusia sebagai sub sistem hukum jaminan kebendaan tidak boleh bertentangan satu sama lainnya, kesatuan jaminan fidusia sebagai sub sistem hukum jaminan kebendaan harus diterapkan terhadap kumpulan unsurunsur yuridis seperti peraturan hukum jaminan fidusia, asas hukum dan pengertian hukumnya.

Pemberian jaminan fidusia merupakan penyediaan bagian harta pemberi fidusia untuk jaminan pemenuhan kewajibannya, artinya pemberi fidusia melepaskan hak pemilikan secara yuridis untuk sementara. Penyerahan secara yuridis artinya benda jaminan masih dapat dipergunakan oleh pemberi fidusia agar bisnisnya tetap berjalan. Jadi dengan demikian dalam perjanjian jaminan fidusia, konstruksi yang terjadi adalah pemberian jaminan fidusia bertindak sebagai pemilik manfaat, sedangkan penerima fidusia sebagai pemilik yuridis. ${ }^{26}$

Berbeda halnya dengan objek fidusia (Pasal 1 angka 2 Undang-Undang No. 42 Tahun 1999), benda jaminan dalam hak tanggungan adalah hak atas tanah berupa hak milik, hak guna usaha, 
hak guna bangunan dan hak pakai atas tanah negara. Pembedaan hak tanggungan dapat juga dilakukan terhadap hak atas tanah berikut bangunan, tanaman dan hasil karya yang merupakan satu kesatuan dengan tanah dan milik pemegang hak atas tanah tersebut. ${ }^{27}$

Secara konseptual hak tanggungan hanya dibebankan atas tanah saja, dan benda-benda yang ada di atasnya memiliki hukum sendiri, ini berarti Undang-Undang Hak Tanggungan menganut asas pemisahan horizontal. Pengecualian asas ini hanya dimungkinkan apabila bangunan/rumah yang ada di atas tanah tersebut adalah kepunyaan dari pemilik hak atas tanah. Pengecualian semacam ini dibenarkan dalam teori hukum. Dalam UndangUndang Pokok Agraria, antara tanah dan bangunan/rumah yang ada di atasnya adalah terpisah dan ini sesuai dengan asas pemisahan horizontal yang dianut dalam hukum adat.

Seiring dengan perkembangan hukum, pembedaan pada benda tidak didasarkan pada benda bergerak dan benda tidak bergerak lagi, seperti yang terdapat dalam hukum perdata tetapi didasarkan pada benda terdaftar dan tidak terdaftar dalam hukum jaminan.

Pendaftaran benda diatur dalam Peraturan Pemerintah (PP) No. 10 Tahun 1961 yang diubah dengan PP No. 24 Tahun 1997, pendaftaran kenderaan bermotor, pendaftaran kapal laut, pendaftaran pesawat terbang dan lain sebagainya. Dalam jaminan hipotik yang menjadi objek adalah kapal yang beratnya paling sedikit $20 \mathrm{~m} 3$ dan telah terdaftar (Pasal 314 Kitab Undang-Undang Hukum Dagang).

Hipotik juga dapat dibebankan atas pesawat udara dan helikopter yang telah memiliki tanda pendaftaran dan kebangsaan Indonesia. Penekanan objek hipotik terletak pada aspek pendaftaran dari kapal, pesawat udara dan helikopter. Ini menunjukkan bahwa pendaftaran

\footnotetext{
${ }^{27}$ Lihat Pasal 4 jo Penjelasan Umum angka (6) UU
} No. 4 Tahun 1996. memberikan fungsi yuridis untuk menetapkan benda tersebut dianggap sebagai benda tidak bergerak yang menjadi objek hipotik. Sebagai konsekuensinya jika pesawat udara, helikopter itu tidak terdaftar tentunya tidak dapat dibebani dengan jaminan hipotik dan alternatif yang dapat diterapkan adalah lembaga gadai (pand) dan jaminan fidusia.

Dengan menggunakan lembaga gadai atas kapal, pesawat dan helikopter tentunya barang jaminan harus diserahkan kepada kreditur pemegang gadai (Pasal 1152 ayat (2) Kitab Undang-Undang Hukum Perdata), dan ini sangat merugikan debitur, alternatif jaminan yang lebih menguntungkan untuk kapal, pesawat udara dan helikopter yang tidak terdaftar adalah jaminan fidusia (Pasal 31 UU No. 42 Tahun 1999).

Fidusia sebagai salah satu jaminan adalah unsur pengaman kredit bank, yang dilahirkan dengan didahului oleh perjanjian kredit bank. Ini Menunjukkan jaminan fidusia memiliki karakter assessoir (tambahan). Sebagai hak kebendaan, jaminan fidusia mempunyai hak didahulukan terhadap kreditur lain (droit de preferent) untuk mengambil pelunasan piutangnya atas hasil eksekusi benda jaminan fidusia.

Hak untuk mengambil pelunasan ini mendahului kreditur-kreditur lain. Bahkan sekalipun pemberi fidusia dinyatakan pailit atau dilikuidasi (Pasal 27 UU No. 42 Tahun 1999), hak didahulukan dari penerima fidusia tidak hapus karena benda yang menjadi objek jaminan fidusia tidak termasuk dalam harta pailit pemberi fidusia. Dengan demikian penerima fidusia tergolong dalam kelompok kreditur separatis.

Dalam Pasal 33 Undang-Undang Jaminan Fidusia dinyatakan bahwa setiap janji yang memberi kewenangan kepada penerima fidusia untuk memiliki benda yang menjadi objek jaminan fidusia apabila debitur cidera janji, batal demi hukum. Dengan demikian objek jaminan fidusia tidak menjadi bagian harta pailit 
penerima fidusia oleh karena hak kepemilikan atas objek jaminan fidusia tersebut diperolehnya semata-mata sebagai jaminan

Hak kebendaan jaminan fidusia baru lahir pada tanggal dicatatnya jaminan fidusia dalam buku daftar fidusia dan sekaligus untuk memenuhi asas publisitas. Karena itu konsekuensi yuridis adalah kalau jaminan fidusia tidak dicatatkan dalam buku daftar fidusia berarti hak jaminan fidusia bukan merupakan hak kebendaan yang memiliki sifat kebendaan tetapi memiliki karakter perorangan akibatnya kreditur fidusia tidak dapat dilindungi dengan asas droit de suite dan berkedudukan sebagai kreditur konkuren bukan kreditur preferen.

Proses pembuatan jaminan fidusia harus dilakukan secara sempurna mulai dari tahap perjanjian kredit, pembuatan akta jaminan fidusia oleh notaris dan diikuti dengan pendaftaran akta jaminan fidusia pada kantor pendaftaran fidusia. Tahapan proses perjanjian fidusia tersebut memiliki arti yang berbeda sehingga memberi karakter tersendiri dengan segala akibat hukumnya.

Dalam permasalahan tersebut, seharusnya peran pemerintah dapat membuka akses keuangan kreditan kepada pengusaha-pengusaha karena pedagang sebagian besar adalah pedagang pribumi, ketika pemerintah tertuju pada perbankan melalui Bank Indonesia bagaimana bank-bank di Indonesia memberikan sosialisasi untuk memikirkan permasalahan ini dan bekerjasama dengan Kementerian Hukum dan Hak Asasi Manusia (KEMENKUMHAM) RI. dapat menerima kios ini, karena dapat diterimanya kios ini sebagai jaminan sehingga bank-bankpun bisa mengerti kios tersebut dapat dijaminkan dan KEMENKUMHAM dapat membuka model baru sehingga tidak lagi terjadi persoalan tersebut, kantor notaris dan dinas pasar berkomunikasi dengan pemerintah agar bisa menjelaskan bahwa kios tersebut dapat dijaminkan ke perbankan.

1. Disebabkan dari rigiditas dari hukum kebendaan maka untuk melahirkan hak kebendaan atas tempat usaha atau SHPTU direkomendasikan untuk menggunakan kaedah yang terkandung dalam Pasal 48-49 tentang undang-undang Rumah Susun dengan menerbitkan Sertifikat Kepemilikan Bangunan dan Gedung (SKBG), dimana penerbitan sertifikat adalah sama antara Pemerintah Daerah dalam hal ini Dinas Pekerjaan Umum dan Dinas Perumahan, sementara pengelolaan tetap saja PD Pasar Jaya seperti yang sudah berjalan selama ini. Kewenangan penerbitan atas penerbitan sertifikat tidak pada PD Pasar Jaya akan tetapi lembaga yang berwenang atas penerbitan SKBG tersebut. Jika merujuk pada UndangUndang Bangunan Gedung penerbitan SKBG pada Dinas Pekerjaan Umum, dan jika merujuk pada Undang-Undang Rumah Susun maka penerbitan SKBG oleh Dinas Perumahan. Dengan begitu maka terjamin kepastian hukum sebagaimana yang diamanatkan oleh Negara hukum, serta grand theory Hans Kelsen. SKBG merupakan jalan keluar bukti kepemilikan kios, karena nilai yang sangat mahal maka perlu diperlukan kepastian hukum tentang hak kebendaan.

\section{Kesimpulan}

Dari pembahasan sebagaimana di atsa, berikut adalah kesimpulan yang menjadi hasil kajian ini:

1. Pendaftaran hak kebendaan berupa Hak Milik Kios/Los hendaklah dipisahkan dari pendaftaran atas tanah yang dilakukan oleh instansi yang dibentuk oleh pemerintah, dapat saja instansi tersebut pada tatanan otonomi daerah di Kabupaten/Kota, sehingga Los/Kios dapat dijaminkan oleh pedagang dengan harga yang 
beranekaragam kepada lembaga keuangan dalam hal ini perbankan. Sebagaimana terjadi di Perusahaan Daerah (PD) Pasar Jaya khususnya Pasar Tanah Abang Jakarta yang di atasnya terdapat los/kios yang terpisah dari tanah kepemilikannya, akan tetapi sama sekali tidak terdaftar. Adapun hak pemakaian tempat usaha sebagaimana diatur dalam Pasal 9 ayat

(2) Peraturan Daerah Khusus Ibukota (DKI) Jakarta Nomor: 6 Tahun 1992 tentang Pengelolaan dan Pengembangan Pasar merupakan suatu hak untuk memakai atas kebendaan berwujud dari tempat usaha pada bangunan pasar yang dimiliki dan dapat dialihkan. Akan tetapi tidak dapat dijadikan jaminan kredit baik kredit modal kerja maupun kredit pemilikan Hak Pemakaian Tempat Usaha, karena hanya memperoleh Sertifikat Hak Pemakaian Tempat Usaha (SHPTU) dan Surat izin Pemakaian Tempat Usaha (SIPTU).

2. Disebabkan dari rigiditas dari hukum kebendaan maka untuk melahirkan hak kebendaan atas tempat usaha atau SHPTU direkomendasikan untuk menggunakan kaedah yang terkandung dalam Pasal 48-49 tentang UndangUndang Rumah Susun dengan menerbitkan Sertifikat Kepemilikan Bangunan dan Gedung (SKBG), dimana penerbitan sertifikat adalah sama antara Pemerintah Daerah dalam hal ini Dinas Pekerjaan Umum dan Dinas Perumahan, sementara pengelolaan tetap saja PD Pasar Jaya seperti yang sudah berjalan selama ini. Kewenangan penerbitan atas penerbitan sertifikat tidak pada PD Pasar Jaya akan tetapi lembaga yang berwenang atas penerbitan SKBG tersebut. Jika merujuk pada UndangUndang Bangunan Gedung penerbitan SKBG pada Dinas Pekerjaan Umum, dan jika merujuk pada UndangUndang Rumah Susun maka penerbitan SKBG oleh Dinas Perumahan. Dengan begitu maka terjamin kepastian hukum sebagaimana yang diamanatkan oleh Negara hukum, serta grand theory Hans Kelsen. SKBG merupakan jalan keluar bukti kepemilikan kios, karena nilai yang sangat mahal maka perlu diperlukan kepastian hukum tentang hak kebendaan.

\section{DAFTAR PUSTAKA}

C. R. Noyes, 1936, The Institution of Property, New York.

Djuhaendah Hasan, 1996, Lembaga Jaminan Kebendaan Bagi Tanah Dan Benda Lain Yang Melekat Pada Tanah Dalam Konsepsi Penerapan Asas Pemisahan Horisontal: Suatu Konsep Dalam Menyongsong Lahirnya Lembaga Hak Tanggungan (Citra Aditya Bakti).

Frieda Husni Hasbullah, 2005, Hukum Kebendaan Perdata: Hak-Hak yang Memberi Kenikmatan.

J. Satrio, 1999, Perikatan Pada Umumnya, Bandung : Alumni.

Jimly Asshidiqie dan Ali Safa`at, 2006, Teori Hans Kelsen tentang Hukum, Jakarta, Sekjen dan Kepaniteraan MK-RI.

Lawrence M. Friedmann, American Law, W.W Norton dan Company: New York London, 1984.

Lili Rasjidi dan Ida Bagus Wiyasa Putra, 2003, Hukum Sebagai Suatu Sistem, Penerbit: CV. Mandar Maju, Bandung. 
M. Yahya Harahap, 2006, Pembahasan, Permasalahan dan Penerapan KUHAP, Edisi Kedua, Jakarta, Sinar Grafika.

Mariam Darus Badrulzaman, 1983, Mencari Sistem Hukum Benda Nasional, Alumni: Bandung.

Martin Roestamy, 2009, Hukum Jaminan Fidusia (Perlindungan Hukum Kepada Kreditur Pemegang Jaminan Fidusia Benda tidak Terdaftar), Bogor UNIDA Press.

Martin Roestamy, Hukum Jaminan Fidusia (Perlindungan Hukum Kepada Kreditur Pemegang Jaminan Fidusia Benda tidak Terdaftar), Bogor UNIDA Press, 2009.

Martin Roestamy, 2008, Kepastian Hukum Atas Kepemilikan Rumah Dan Bangunan Gedung Oleh Investor Asing Dikaitkan Dengan Asas Nasionalitas Dalam Sistem Huum Pertanahan Indonesia, yang dipertahankan dalam sidang terbuka, di Universitas Padjadjaran.

Martin Roestamy, 2015, Metodologi Penelitian Hukum, Bahan Matakuliah MPH, Sekolah Pascasarjana Universitas Djuanda Bogor.

Mochtar Kusumaatmadja, 2002, Konsep-Konsep Hukum Dalam Pembangunan (Kumpulan Karya Tulis) Penerbit Alumni, Bandung.

Mochtar Kusumaatmadja, Fungsi dan Perkembangan Hukum dalam Pembangunan Nasional, Penerbit Bina Cipta, Bandung, tanpa tahun.

Philipus M. Hadjon, 1987, Perlindungan Hukum Bagi Masyarakat Indonesia, Jakarta : Bina Ilmu.

Satjipto Rahardjo, 1984, .Hukum dan Masyarakat, Angkasa: Bandung.

Satjipto Rahardjo, 2006, Menggagas Hukum Progresif Indonesia, Yogyakarta : Pustaka Pelajar.

Sri Soedewi Masjchoen Sofwan, Hukum Perdata: Hukum Benda, Liberty, Yogyakarta.

Winahyu Erwiningsih, 2009, Hak Menguasai Negara Atas Tanah, Universitas Islam Indonesia, Fakultas Hukum Program Pascasarjana, Total Media.

http://www.jualsewakios.com/tag/tanah-abang/, diakses pada tanggal 16 Agustus 2016.

Hadi Wijaya, http://www.telingamata.com/kios-di-tanah-abang-lebih-mahal-dari-tokyodan-new-york/ di akses pada tanggal 14 Agustus 2016

http://www.apartemensingapore.info/cara-membeli-apartemen-di-singapura/\#.WKDqvlyfDc diakses pada tahun 2014 Huttons Asia Pte Ltd

Wawancara pada hari Kamis, tanggal 15 September 2016, di Bank BRI Cabang Cut Mutia Jakarta, staf administrasi kredit, Dani Suhendro, SE. 